\title{
HUBUNGAN ANTARA TEKNIK MENERAN DENGAN RUPTURA PERINIUM PADA IBU BERSALIN YANG SELAMA KEHAMILAN MENGIKUTI SENAM HAMIL (STUDI KASUS DI BPM NY. WIWIK S. AENGSAREH SAMPANG)
}

\author{
Safrita Arlina Alfiani ${ }^{1}$, Yefi Marliandiani ${ }^{2}$ \\ 1. Mahasiswa Prodi D-III Kebidanan Universitas PGRI Adi Buana Surabaya \\ 2. Tenaga Pengajar Prodi D-III Kebidanan Universitas PGRI Adi Buana Surabaya
}

\begin{abstract}
ABSTRAK
Penyebab robekan perineum umumnya terjadi pada faktor predisposisi salah satunya faktor ibu yaitu teknik meneran. Namun ibu dapat melakukan teknik meneran dengan benar dengan mengikuti senam hamil. Salah satu manfaat senam hamil, ibu dapat melakukan teknik mengejan dengan baik .Penelitian ini bertujuan untuk mengetahui hubungan antara teknik meneran dengan ruptur penineum pada ibu bersalin yang selama kehamilan mengikuti senam hamil. Dalam penelitian ini digunakan metode analitik dan menggunakan purposive sampel yaitu pengambilan sampel yang didasarkan pada suatu pertimbangan tertentu yang dibuat oleh peneliti sendiri, berdasarkan ciri atau sifat-sifat populasi yang sudah diketahui sebelumnya. Sampel ibu bersalin yang pada waktu hamil mengikuti senam hamil sebanyak 30 responden.Instrumen yang digunakan adalah dengan observasi menggunakan ceklis,baik pada teknik meneran maupun pada ruptur perineum.Berdasarkan hasil penelitian yang telah dilakukan diperoleh hasil bahwa dari 30 responden, melakukan teknik meneran dengan benar pada kala II sebagian besar tidak terjadi rupture perineum yaitu sebanyak $77 \%$, dan responden dengan teknik meneran yang salah pada kala II yang terbanyak mengalami rupture perineum sebanyak $82 \%$, dan dari hasil chi-square didapatkan Ho ditolak, Ha diterima maka dapat disimpulkan bahwa ada hubungan antara teknik meneran dengan ruptur perineum pada ibu bersalin yang selama kehamilan mengikuti senam hamil. Dengan kolerasi salahnya meneran pada ibu bersalin yang selama kehamilan mengikuti senam hamil tidak rutin maka terjadi ruptur perineum semakin banyak. Oleh sebab itu bidan disarankan untuk melakukan pemantauan pada ibu-ibu yag mengikuti senam hamil untuk melihat benar tidaknya latihan meneran, latihan pernafasan dan relaksasi, penguatan otot panggul dan perut saat diadakan latihan senam hamil.
\end{abstract}

Kata Kunci : Ruptur perineum, teknik meneran, senam hamil

\section{PENDAHULUAN}

Dalam upaya mempercepat penurunan $\mathrm{AKI}$, sekaligus untuk mencapai target $\mathrm{AKI}$ menjadi 125/100.000 kelahiran hidup pada tahun 2010, dan sasaran Millenium Development Goals (MDGs) menjadi 102/100.000 kelahiran hidup pada tahun 2015, salah satu upaya yang dilakukan adalah Making Pregnancy Safer (MPS) yang diprakarsai oleh WHO dan merupakan strategi sektor kesehatan yang bertujuan menurunkan AKI.

Perdarahan akibat luasnya luka jalan lahir merupakan penyebab kedua perdarahan post partum setelah atonia uteri yang terjadi pada hampir semua persalinan pertama dan tidak jarang terjadi pada persalinan berikutnya. Pada seorang primipara atau orang yang baru pertama kali melahirkan ketika terjadi peristiwa "kepala keluar pintu", pada saat ini seorang primipara biasanya tidak dapat menahan reflek dorongan meneran yang kuat, sehingga dapat terjadi robekan pada pinggir depan perineum yang tidak dapat dihindari. Sebagai akibat persalinan terutama pada seorang primipara, biasa timbul luka pada vulva disekitar introitus vagina yang biasanya tidak terlalu dalamnamun kadang-kadang bisa timbul perdarahan banyak. (Prawirohardjo, 2010).

Senam hamil merupakan salah satu kegiatan dalam pelayanan selama kehamilan (prenatal care). Senam hamil akan memberikan suatu hasil produk kehamilan (out come) persalinan yang lebih baik dibandingkan pada ibu-ibu hamil yang tidak 
melakukan senam hamil (Depkes RI, 2005). Senam hamil adalah suatu bentuk latihan guna memperkuat dan mempertahankan elastisitas otot-otot dinding perut, ligamenligamen, otot dasar panggul yang berhubungan dengan proses persalinan (Hanafi, 2008).

Berdasarkan studi pendahuluan yang dilakukan pada 5 orang ibu bersalin ditemukan 2 orang ibu dengan teknik meneran yang salah dan mengalami ruptur perineum sehingga hal terebut dapat menimbulkan komplikasi yaitu perdarahan dan infeksi. Peneliti melakukan penelitian di BPM Ny.Wiwik S.Aengsareh Sampang karena belum ada yang melakukan penelitian tentang hubungan teknik meneran dengan kejadian ruptur perineum pada ibu bersalin yang selama kehamilan mengikuti senam hamil dan di BPM Wiwik terdapat kelas senam hamil yang rutin diadakan setiap seminggu sekali.

Rumusan masalah pada penelitian ini adalah adakah hubungan antara teknik meneran dengan kejadian ruptur perineum pada ibu bersalin yang selama kehamilan mengikuti senam hamil di BPM Ny.Wiwik S.Aengsareh Sampang.

Tujuan umum penelitian ini adalah untuk mengetahui hubungan antara teknik meneran dengan kejadian ruptur penineum pada ibu bersalin yang selama kehamilan mengikuti senam hamil di BPM Ny.Wiwik S.Aengsareh Sampang

Tujuan khususnya adalah 1) Mengidentifikasi teknik meneran ibu bersalin pada ibu yang selama kehamilan mengikuti senam hamil di BPM Ny.Wiwik S.Aengsareh Sampang 2) Mengidentifikasi ruptur perineum pada ibu bersalin yang selama kehamilan mengikuti senam hamil di BPM Ny. Wiwik S.Aengsareh Sampang 3) Menganalisis hubungan antara teknik meneran dengan kejadian ruptur perineum pada ibu bersalin yang selama kehamilan mengikuti senam hamil diBPM Ny.Wiwik S.Aengsareh Sampang.

\section{BAHAN DAN METODE}

Dalam penelitian ini menggunakan desain penelitian analitik. Penelitian analitik korelasional adalah penelitian yang menjawab mengapa dan adakah hubungan antara teknik meneran dengan kejadian ruptur perineum pada ibu bersalin yang selama kehamilan mengikuti senam hamil di BPM Ny.Wiwik S.Aengsareh Sampang.

Pada penelitian ini populasinya adalah semua ibu bersalin yang mengalami proses persalinan normal (fisiologis) di BPM Ny.Wiwik S.Aengsareh Sampang. Jumlah persalinan rata-rata perbulan \pm 35 orang.

Sampel dalam penelitian ini adalah sebagian populasi yang mempunyai kriteria inklusi yaitu ibu yang mengikuti senam hamil selama kehamilan ini dan yang bersalin selama bulan April-juni 2013.Besar sampel pada penelitian ini adalah sebanyak 30 responden, sedangkan teknik sampel pada penelitian ini menggunakan purposive sampel yaitu pengambilan sampel yang didasarkan pada suatu pertimbangan tertentu yang dibuat oleh peneliti sendiri, berdasarkan ciri atau sifat-sifat populasi yang sudah diketahui sebelumnya. Adapun pengambilan sampel dalam penelitian ini dengan cara mengambil responden yang bersalin pada bulan AprilJuni 2013 di BPM Ny.Wiwik S. Aengsareh Sampang sesuai urutan dan yang memenuhi kriteria inklusi sampai terpenuhinya jumlah responden yang ditentukan.Dalam penelitian ini instrumen yang digunakan adalah dengan observasi menggunakan ceklis, baik pada teknik meneran maupun pada ruptur perineum.

\section{HASIIL DAN PEMBAHASAN}

\begin{tabular}{|c|c|c|c|}
\hline No & $\begin{array}{c}\text { Jumlah } \\
\text { Anak }\end{array}$ & $\begin{array}{c}\text { Frekuensi } \\
\text { (f) }\end{array}$ & $\begin{array}{c}\text { Persentase } \\
(\%)\end{array}$ \\
\hline \hline 1 & 1 & 9 & 30 \\
2 & $2-5$ & 19 & 63 \\
3 & $>5$ & 2 & 7 \\
\hline \multicolumn{2}{|r|}{ Jumlah } & 30 & 100 \\
\hline
\end{tabular}

\section{Data jumlah anak (Paritas) ibu bersalin}

Tabel 1. Distribusi frekuensi responden menurut jumlah anak yang dimiliki di BPS Wiwik S, Sampang periode April - Juni 2013 Tabel 1. dapat dijelaskan bahwa berdasarkan jumlah anak dari 30 responden yang terbanyak dengan jumlah anak 2-5 orang yaitu sebanyak 19 responden (63\%).

Data hasil penelitian tentang teknik meneran pada ibu bersalin yang selama kehamilan mengikuti senam hamil

Tabel 2. Distribusi frekuensi berdasarkan teknik meneran pada ibu bersalin yang 
selama kehamilan mengikuti senam hamil di BPS Wiwik S, Aengsareh Kabupaten Sampang, periode April -Juni 2013.

\begin{tabular}{|c|c|c|c|}
\hline No & $\begin{array}{c}\text { Teknik } \\
\text { Meneran }\end{array}$ & $\begin{array}{c}\text { Frekuiensi } \\
(\mathbf{f})\end{array}$ & $\begin{array}{c}\text { Persentase } \\
\text { (\%) }\end{array}$ \\
\hline \hline 1 & Benar & 13 & 4 \\
2 & Salah & 17 & 57 \\
\hline \multicolumn{2}{|c|}{ Jumlah } & 30 & 100 \\
\hline
\end{tabular}

Tabel 2 dapat dijelaskan bahwa berdasarkan teknik meneran pada ibu bersalin dari 30 responden terbanyak yaitu dengan teknik meneran yang salah sebanyak 17 orang (57\%).

Data kejadian ruptur perineum pada Ibu bersalin yang selama kehamilan mengikuti senam hamil

Tabel 3. Distribusi frekuensi kejadian ruptur perineum pada ibu bersalin di BPS

\begin{tabular}{|c|c|c|c|}
\hline $\begin{array}{l}\mathbf{N} \\
\mathbf{0}\end{array}$ & $\begin{array}{c}\text { Ruptur } \\
\text { perineu } \\
\mathbf{m} \\
\end{array}$ & $\begin{array}{c}\text { Frekuensi(f } \\
) \\
\end{array}$ & $\begin{array}{c}\text { Persentase(\% } \\
)\end{array}$ \\
\hline $\begin{array}{l}1 \\
2\end{array}$ & $\begin{array}{c}\text { Ada } \\
\text { Tidak } \\
\text { Ada } \\
\end{array}$ & $\begin{array}{l}17 \\
13\end{array}$ & $\begin{array}{l}57 \\
43\end{array}$ \\
\hline \multicolumn{2}{|c|}{ Jumlah } & 30 & 100 \\
\hline
\end{tabular}

Tabel 3, menunjukan bahwa dari 30 responden, terbanyak yaitu terjadi ruptur perineum sebanyak 17 orang (57\%).

Data hubungan antara teknik meneran dengan kejadian ruptur perineum pada Ibu besalin yang selama kehamilan mengikuti senam hamil

Tabel 4. Tabel Silang antara teknik meneran dengan kejadian ruptur perineum di BPS Wiwik S, Aengsareh Sampang periode April-Juni 2013

Berdasarkan table 4, diperoleh hasil bahwa dari 13 responden yang melakukan teknik meneran dengan benar pada kala II sebagian besar tidak terjadi ruptur perineum yaitu sebanyak 10 responden (77\%), dan 17 responden dengan teknik meneran yang salah pada kala II yang terbanyak mengalami ruptur perineum sebanyak 14 responden (82\%).

\section{Teknik Meneran pada Ibu Bersalin Kala II} Berdasarkan hasil penelitian menunjukkan bahwa dari 30 orang ibu bersalin yang selama kehamilan mengikuti senam hamil terbanyak didapatkan 17 responden $(57 \%)$ melakukan teknik meneran yang salah sedangkan 13 responden (43\%) ibu bersalin pada kala II melakukan teknik meneran yang benar.

Menurut Mandriawati (2008) tujuan senam hamil untuk memperkuat dan mempertahankan elatisitas otot-otot dinding perut, ligament-ligamen, otot dasar panggul yang berhubungan dengan proses persalinan serta latihan mengejan, latihan ini khusus untuk menghadapi persalinan, agar mengejan secara benar sehingga bayi dapat lancar keluar dan tidak tertahan di jalan lahir.

Menurut Sekar Ayu (2012) manfaat senam hamil salah satunya adalah memudahkan persalinan normal sehingga tidak menimbulkan rasa sakit yang amat sangat, karena ibu sudah dapat melakukan pernafasan untuk mengejan dengn baik.

Berdasarkan data yang diperoleh teknik meneran pada ibu bersalin mayoritas melakukan teknik meneran yang salah yang berpontensi terjadi ruptur perineum hal ini terjadi pada ibu yang tidak melakukan senam hamil secara rutin, sehingga senam hamil sangat berpengaruh pada teknik meneran dengan kejadian ruptur perineum.

Kondisi kelas latihan senam hamil di BPM Wiwik S, Aengsareh Sampang,latihan dilaksanakan pada ibu hamil yang usia kehamilannya memasuki usia 28 minggu, senam hamil dilaksanakan satu minggu sekali oleh instruktur senam hamil. Setelah senam berakhir instruktur menyarankan untuk menerapkan senam hamil dirumah tapi tanpa ada pemantauan ibu menerapkannya dirumah, yaitu dengan cara nenanyakan

\begin{tabular}{|c|c|c|c|c|c|c|c|}
\hline \multirow{3}{*}{ NO } & \multirow{3}{*}{$\begin{array}{c}\text { Teknik } \\
\text { Menera } \\
\mathbf{n}\end{array}$} & \multicolumn{4}{|c|}{ Ruptur Perineum } & \multirow{2}{*}{\multicolumn{2}{|c|}{ Jumlah }} \\
\hline & & \multicolumn{2}{|c|}{ Ada } & \multicolumn{2}{|c|}{ Tidak Ada } & & \\
\hline & & $\mathrm{N}$ & $\%$ & $\mathrm{~N}$ & $\%$ & $\mathrm{~N}$ & $\%$ \\
\hline 1. & Benar & 3 & $23 \%$ & 10 & $77 \%$ & 13 & 100 \\
\hline 2. & Salah & 14 & $82 \%$ & 3 & $18 \%$ & 17 & 100 \\
\hline \multicolumn{2}{|c|}{ Jumlah } & 17 & $57 \%$ & 13 & $43 \%$ & 30 & 100 \\
\hline
\end{tabular}

kepada ibu dan keluarga saat kunjungan ulang apakah ibu menerapkan senam hamil dirumah atau tidak.

\section{ANALISA DATA}


Menurut JNPK-KR (2008) teknik meneran yang benar yaitu:

a. Anjurkan ibu untuk meneran sesuai dengan dorongan alamiahnya selama kontraksi.

b. Beritahu untuk tidak menahan nafas pada saat meneran.

c. Minta ibu untuk berhenti meneran dan beristirahat diantara kontraksi.

d. Jika ibu berbaring miring atau setengah duduk, ibu mungkin merasa lebih mudah untuk meneran jika ia menarik lutut kearah dada dan menempelkan dagu ke dada.

e. Minta ibu untuk tidak mengangkat bokong saat meneran.

f. Tidak diperbolehkan untuk mendorong fundus untuk membantu kelahiran bayi.

Kondisi saat ibu memasuki persalinan kala I bidan memeberikan bimbingan, salah satunya tentang teknik meneran yang benar, sehingga hal ini dapat diterapkan ibu langsung saat memasuki kala II.

Kejadian pada ibu yang melakukan teknik meneran yang salah pada kala II tersebut didapatkan pada ibu yang tidak melakukan senam hamil secara rutin, hal ini dapat terjadi karena ibu mengikuti senam hamil kurang berkonsentrasi, tidak menerapkannya dirumah, dan saat memasuki kala I ibu tidak mendapat pengajaran tentang teknik meneran yang benar dari bidan. Dari faktor lain dapat juga terjadi pada ibu primigravida yang belum siap menghadapi persalinan atau belum mempunyai pengalaman bersalin hal ini berdasarkan tabel 5.2 dapat dijelaskan bahwa berdasarkan jumlah anak dari 30 responden yang jumlah anak 1 orang yaitu sebanyak 9 responden $(30 \%)$ sehingga pengalaman seseorang tentang teknik meneran dapat diperoleh dari jumlah anak atau paritas, dan dapat dipengaruhi oleh usia terlalu muda berdasarkan tabel 5.1 dapat dijelaskan bahwa dari 30 responden ibu yang bersalin normal di BPM Ny. Wiwik S. Aengsareh Kabupaten Sampang mayoritas yang berumur antara $<20$ tahun yaitu sebanyak 8 responden (27\%).

Menurut Notoadmojo (2003), bahwa dengan bertambahnya umur maka tingkat perkembangan akan berkembang sesuai dengan pengetahuan yang pernah didapatkan dan juga dari pengalaman sendiri. Maka dari itu pengetahuan ibu tentang teknik meneran yang di ajarkan saat latihan senam hamil dapat mempengaruhi teknik meneran saat bersalin.
Pada ibu bersalin melakukan teknik meneran dengan benar ini terjadi pada ibu yang mengikuti senam hamil secara rutin dan saat memasuki kala I bidan tersebut mengajari kembali teknik meneran dengan benar, bidan menjadi lebih mudah mengajarkan pada ibu yang melaksanakan senam hamil secara rutin dibandingkan pada ibu yang tidak rutin, sehingga dapat langsung menerapkannya saat memasuki kala II

\section{Kejadian Ruptur Perineum pada lbu Bersalin Kala II}

Berdasarkan hasil pengolahan data dan kriteria terdapat atau tidaknya robekan perineum dari 30 responden didapatkan 17 responden $(57 \%)$ mengalami ruptur perineum dan 13 responden (43\%) tidak mengalami ruptur perineum.

Menurut Marmi (2012) penyebab robekan perineum salah satunya dari teknik meneran secara fisiologis ibu akan merasakan dorongan untuk meneran bila pembukaan sudah lengkap dan reflek ferguson telah terjadi. Ibu harus didukung untuk meneran dengan benar pada saat ia merasakan dorongan dan memang ingin mengejan. Ibu mungkin merasa dapat meneran secara lebih efektif pada posisi tertentu. Beberapa cara yang dapat dilakukan dalam memimpin ibu bersalin melakukan meneran untuk mencegah terjadinya rupture perineum, diantaranya : menganjurkan ibu untuk meneran sesuai dengan dorongan alamiahnya selama kontraksi, tidak menganjurkan ibu untuk menahan nafas pada saat meneran, mungkin ibu akan merasa lebih mudah untuk meneran jika ibu berbaring miring atau setengah duduk, menarik lutut kearah ibu, dan menempelkan dagu kedada, menganjurkan ibu untuk tidak mengangkat bokong saat meneran,

Pada ibu yang terjadi ruptur perineum saat bersalin, dikarenakan ibu dengan teknik meneran yang salah, hal ini dapat terjadi juga pada ibu primigravida dan bayi besar.

Pada ibu dengan tidak terjadi ruptur perineum didapatkan pada ibu yang melakukan teknik meneran dengan benar, ibu dengan kehamilan multipara dan grandemultipara,

Hubungan antara Teknik Meneran dengan Kejadian Ruptur Perineum pada lbu 


\section{Besalin yang Selama Kehamilan Mengikuti Senam Hamil}

Berdasarkan uji hipotesis ada hubungan yang kuat antara teknik meneran dengan kejadian ruptur perineum yang selama kehamilan mengikuti senam hamil

Pada ibu bersalin dengan melakukan teknik meneran dengan benar dan terjadi ruptur perineum terdapat 3 responden (23\%) hal ini dapat terjadi pada ibu primigravida, usia yang terlalu muda dan bayi dengan berat lahir besar, pada ibu bersalin yang tidak ada ruptur perineum terdapat 10 responden (77\%) pada ibu bersalin yang mengikuti senam hamil secara rutin, hal ini terjadi pada ibu yang menerapkan senam hamil dirumah, berkonsentrasi saat mengikuti kelas senam hamil, pada ibu yang berusia cukup untuk hamil dan pada ibu yang multipara atau grandemultipara, pada ibu dengan melakukan teknik meneran yang salah dan terjadi ruptur perineum terdapat 14 responden (82\%) terjadi pada ibu yang tidak mengikuti senam hamil secara rutin, dapat terjadi saat mengikuti senam hamil kurang berkonsentrasi, tidak menerapkannya dirumah, dan ibu bersalin yang tidak terjadi ruptur perineum terdapat 3 responden (18\%) terjadi pada ibu dengan kehamilan grandemultipara.

Dampak meneran yang salah menurut Dini (2011) salah satunya adalah bila mengejan sambil mengangkat bokong, selain membuat proses mengejan tidak maksimal, juga bisa memperparah robekan perineum (daerah antara vagina dengan anus).

\section{Simpulan dan Saran}

Berdasarkan uraian hasil penelitian dan pembahasan yang telah dijabarkan pada BAB 5 dan 6 maka peneliti dapat menarik kesimpulan sebagai berikut 1) Teknik meneran pada ibu bersalin yang selama kehamilan mengikuti senam hamil di BPM Wiwik S, Aengsareh Sampang mayoritas salah. 2) Ruptur perineum pada ibu bersalin yang selama kehamilan mengikuti senam hamil di BPM Wiwik S, Aengsareh Sampang mayoritas terjadi rupture perineum. 3) Terdapat hubungan yang kuat antara teknik meneran dengan kejadian ruptur perineum pada ibu bersalin yang selama kehamilan mengikuti senam hamil di BPM Wiwik $S$, Aengsareh Sampang.

Berdasarkan hasil penelitian maka disarankan sebagai berikut:
1) bagi BPM agar melakukan pemantauan pada ibu-ibu yang mengikuti senam hamil untuk melihat benar tidaknya latihan meneran saat latihan senam hamil dengan cara pendekatan dari satu ibu ke ibu lainnya, dan melakukan pemantauan pada ibu yang menerapkan senam hamil di rumah dengan cara menanyakan kembali kepada ibu saat kunjungan ulang dan kepada keluarga untuk mengklarifikasi apakah ibu benar-bnear menerapkannya di rumah atau tidak.

2) Bagi ibu hamilagar melakukan senam hamil secara rutin, saat mengikuti senam hamil diharapkan berkonsentrasi, dan menerapkannya dirumah sehingga dalam proses persalinan dapat melakukan teknik meneran dengan benar.

3) Bagi Peneliti Selanjutnya diharapkan dapat meneliti faktor-faktor lain yang mempengaruhi teknik meneran yang salah pada ibu yang telah mengikuti latihan senam hamil selama kehamilannya yaitu pada frekuensi rutinnya ibu mengikuti senam hamil, dukungan dari keluarga dan dari faktor pekerjaan ibu.

\section{DAFTAR PUSTAKA}

Annisa, Dini (2011).Mengejan.SeninJuli 2013. $\mathrm{http} /$ /itbmotherhood.com

Ayu, Sekar(2012). Kursus Kilat Senam Hamil Untuk Menjaga Kehamilan Sehat \& PersalinanNormal. Jakarta: Araska

Burhan, Bungin M (2010). Metodologi Penelitian Kuantitatif. Jakarata: Kencana

Dorland (1998). Kamus Saku Kedokteran Dorland. Jakarta: EGC

Hidayat, Aziz Alimul (2010). Metode Penelitian Kebidanan \& Teknik Analisa Data. Jakarta : Salemba Medika

JNPK-KR (2008). Pelatihan Klinik Asuhan Persalinan Normal. Jakarta : Jaringan Nasional Pelatihan Klinik Kesehatan Reproduksi Departemen Kesehatan Republik Indonesia 
Mandriwati,G.A.2008.

PenuntunBelajarAsuhanKebidananlbu

Hamil. Jakarta: EGC

Manuaba, Ida Bagus (2010). Ilmu Kebidanan

Penyakit Kandungan dan Keluarga

Berencana Untuk Pendidikan Bidan. Jakarta : EGC

Marmi (2012). Intranatal Care Asuhan Kebidanan Pada Persalinan. Yogyakarta : Pustaka Pelajar

Notoatmodjo, Soekidjo (2010). Metodologi Penelitian Kesehatan. Jakarta : Rineka Cipta

Oxorn, Harry (2003). Patologi dan Fisiologi Persalinan. Jakarta : Yayasan Essentia Medika

Prawirohardjo, Sarwono ( 2010). Pelayanan kesehatan maternal dan neonatal. Jakarta : PT Bina Pustaka Sarwono Prawirihardjo

Prawirohardjo, Sarwono (2005). IlmuKebidanan. Jakarta : YBPSPRukiyah, Ai Yeyeh (2009).Asuhan Kebidanan II (Persalinan). Jakarta : CV. Trans InfoMedia 